African Crop Science Journal by African Crop Science Society is licensed under a Creative Commons Attribution 3.0 Uganda License. Based on a work at www.ajol.info/ and www.bioline.org.br/cs DOI: http://dx.doi.org/10.4314/acsj.v24i1.17S

\title{
INCIDENCE AND DISTRIBUTION OF INSECT PESTS IN RAIN-FED WHEAT IN EASTERN AFRICA
}

\author{
M. MACHARIA, D. TEBKEW ${ }^{1}$, W. AGUM ${ }^{2}$ and M. NJUGUNA \\ KALRO, Food Crops Research Centre- Njoro, P. O. Private Bag, 20107, Njoro, Kenya \\ ${ }^{1}$ Ethiopian Institute of Agricultural Research, Debre Zeit Center, P. O. Box 32, Debre Zeit, Ethiopia \\ ${ }^{2}$ National Agricultural Research Laboratories, (NARL) Kawanda, P. O. Box 7065, Kampala, Uganda
}

Corresponding author: munenewamacharia@yahoo.com

\begin{abstract}
Insect pests are some of the major constraints limiting yield of wheat (Triticum aestivum L.) in East Africa. The objective of this study was to determine the species composition and distribution of insect pests, and their natural enemies associated with wheat in Eastern Africa. A survey was conducted in farmers' fields in Ethiopia, Kenya and Uganda during 2013 and 2014 cropping season. Wheat fields along roadsides were randomly selected at approximately 2 to $10 \mathrm{Km}$ intervals, and in each field, several wheat plants in a cross diagonal line were examined for presence or absence of insect pests and associate natural enemies. Also, the type of insect was identified to species level and in situ population counts recorded. In Ethiopia, only $39 \%$ of the fields were infested by tef epilachna, Chnootriba similis Thurnberg (Coleoptera: Coccinellidae); while the remaining wheat fields were free of insect infestation. The Russian Wheat Aphid (RWA), Diuraphis noxia Kurdijumov (Hemiptera: Aphididae), was the most prevalent insect pest of wheat in Kenya and Uganda. The maximum number of RWA per tiller was 58 in Kenya and 38 in Uganda. Moreover, in Kenya the rose wheat (grass) aphid (Metopolophium dirhodum Walker), oat-bird-cherry aphid (Rhopalosiphum padi Walker) and corn leaf aphid (R. maidis Fitch) were prevalent, though at low densities ranging, from 0.1 to 9 per tiller. The greenbug (Schizaphis graminum Rondani) and the green stink bug (Nezara viridula L.) were recorded only in Uganda. The general aphid predators Cheilomenes spp., spiders, lacewings and the parasitoid Aphidius spp. were the natural enemies of aphids found in Kenyan wheat. However, the density of these natural enemies was too low to bring the aphid population to a level that causes economic damage.
\end{abstract}

Key Words: Russian Wheat Aphid, Triticum aestivum

\section{RÉSUMÉ}

Les insectes nuisibles d'insecte sont certaines des contraintes importantes limitant la production de blé (Triticum aestivum L.) à Afrique de l'est. L'objectif de cette étude était de déterminer la composition d'espèces et la distribution d'insectes nuisibles d'insecte et de leurs ennemis naturels associés au blé dans l'Afrique de L'est. Une enquête a été accomplie dans les champs de fermiers en Éthiopie, Kenya et Ouganda pendant 2013 et 2014 en coupant la saison. Les champs de blé le long des accotements de route ont été au hasard choisis aux intervalles d'environ 2 à $10 \mathrm{kms}$ et dans chaque champ, plusieurs usines de blé à une ligne diagonale fâchée ont été examinées pour la présence ou l'absence d'insectes nuisibles d'insecte et associent des ennemis naturels. Aussi, le type d'insecte a été identifié au niveau d'espèces et dans les comptes démographiques situ enregistrés. En Éthiopie, seulement $39 \%$ des champs étaient infested par tef epilachna, Chnootriba similis Thurnberg (les coléoptères : Coccinellidae); pendant que les champs de blé restants étaient sans infestation d'insecte. Le Puceron de Blé russe (RWA), Diuraphis noxia Kurdijumov (Hemiptera : Aphididae), était l'insecte nuisible d'insecte le plus qui prévaut de blé au Kenya et à l'Ouganda. Le nombre maximum de RWA par barre était 58 au Kenya et 38 en Ouganda. De plus, au Kenya l'est monté du blé (l'herbe) le puceron (Metopolophium dirhodum le Promeneur), le 
puceron rouge cerise d'oiseau d'avoine (Rhopalosiphum padi le Promeneur) et le puceron de feuille de grain $(R$. maidis Fitch) était qui prévaut, bien qu'aux densités basses variant, de 0.1 à 9 par barre. Les greenbug (Schizaphis graminum Rondani) et le vert puent l'insecte (Nezara viridula L.) a été enregistré seulement en Ouganda. Les prédateurs de puceron généraux Cheilomenes spp., les araignées, lacewings et le parasitoid Aphidius spp. étaient les ennemis naturels de pucerons trouvés dans le blé kényan. Pourtant, la densité de ces ennemis naturels était trop basse pour apporter la population de puceron à un niveau qui provoque le dommage économique.

Mots Clés: le puceron de blé russe, Triticum aestivum

\section{INTRODUCTION}

Wheat (Triticum aestivum L.) is an important cereal crop in Eastern Africa, where it is largely grown by small and large scale farmers. Average wheat yields in the region are about $2.4 \mathrm{tha}^{-1}$ in Ethiopia and $2.5 \mathrm{t} \mathrm{ha}^{-1}$ in Kenya, which are less than the world average of $2.7 \mathrm{t} \mathrm{ha}^{-1}$ (Oerke, 2005). Insect pests are among the major constraints limiting wheat yield in the region. According to Oerke (2005), the average worldwide yield losses of wheat due to insect pests is about $8.7 \%$, and varies depending upon the type of insect pest, control measure applied, type of variety grown and agronomic practices followed.

Although there are no estimates for wheat for Eastern Africa, it is believed that yield losses attributable to insect pests are much greater than the world's average, since crop protection is limited in the region. The objective of this study was to determine the current species composition, distribution and measure the relative importance of wheat insect pests, and identify natural enemies associated with wheat insect pests in eastern Africa.

\section{MATERIALS AND METHODS}

A survey was conducted in fields of major wheat growing areas in Kenya; in East Shewa zone of Ethiopia; and in Bukwo, Kween and Budadiri districts of Uganda in 2013 and 2014 cropping seasons. At every $2-10 \mathrm{Km}$ intervals along accessible roads, several wheat plants in a cross diagonal line were examined for presence or absence of insect pests and associated natural enemies. Where insect infestation was encountered, the type of insect was identified to species level, and in situ population counts were made or visual estimate of damage taken.
In all areas covered by the survey, sampling of cereal aphids was extended to alternate host plants near the crop, in order to identify the host plants. The altitude of surveyed wheat fields ranged from 1600 to 2835 m.a.s.l. The growth stage of the crop was between GS 17 (seven leaves unfolded) in relatively high altitude areas and GS37 (flag leaf just visible) in the lower altitude areas (Zadoks et al., 1974).

\section{RESULTS AND DISCUSSION}

The Russian wheat aphid (RWA), Diuraphis noxia was the most predominant cereal aphid species in Kenya (Table 1). In Kenya, Mount Kenya region had the highest incidence of RWA; followed by West Mau and East Mau region (57.7, 11.7 and 10.2 aphids per tiller, respectively). Uasin Gishu in Kenya had the lowest cereal aphid densities (1.0 aphids per tiller) recorded as most of the farmers planted seed dressed with insecticides (Gaucho 350FS [imidacloprid] and Cruiser 350FS [thiamethoxam]). Other cereal aphid species recorded in Kenya included rose-grain aphid, Metopolophium dirhodum (Walker), corn leaf aphid, Rhopalosiphum maidis (Fitch) and the oat bird cherry aphid, R. padi (L.). However, the population intensities of these aphid species (M. dirhodum, R. maidis, and R. padi), were much less than the population intensity of RWA (Table 1).

Although these aphid species occurred in low intensities, other than the direct wheat damage caused, they are known to be vectors of many viral diseases in cereals, including wheat (Irwin and Thresh, 1988; Gildow 1990). None of these cereal aphid species were found in Ethiopian wheat (Table 2).

According to Hailu et al. (1989), in the main rainy season, cereal aphids are not a problem of 
TABLE 1. Cereal aphid species intensity recorded on wheat in different wheat growing areas in Kenya

\begin{tabular}{lccccc}
\hline Region & \multicolumn{5}{c}{ Number of cereal aphid species per tiller } \\
\cline { 2 - 6 } & $\begin{array}{l}\text { Farms } \\
\text { surveyed }\end{array}$ & $\begin{array}{c}\text { Diuraphis } \\
\text { noxia }\end{array}$ & $\begin{array}{c}\text { Metopolophium } \\
\text { dirhodum }\end{array}$ & $\begin{array}{c}\text { Rhopalosiphum } \\
\text { maidis }\end{array}$ & $\begin{array}{c}\text { Rhopalosiphum } \\
\text { padi }\end{array}$ \\
\hline Mt. Kenya & 25 & 57.7 & 6.3 & 2.4 & 1.5 \\
Laikipia & 7 & 8.6 & 1.3 & 0.1 & - \\
Nyandarua & 4 & 2.5 & - & - & - \\
East Mau & 15 & 10.2 & 3.4 & 3.9 & 3.1 \\
West Mau & 8 & 11.7 & 7.2 & 0.1 & 0.1 \\
Uasin Gishu & 11 & 1.0 & 0.5 & & -1 \\
\hline
\end{tabular}

TABLE 2. Incidence of insect pests on wheat in East and North Shewa zones in Ethiopia

\begin{tabular}{llclll}
\hline Zone & District & Farms surveyed & \multicolumn{2}{c}{ Pest } & Infestation level (\%) \\
\cline { 4 - 5 } & & & Common name & Scientific name & \\
\hline \multirow{2}{*}{ East Shewa } & Adaa & 3 & Tefepilachna & Chnootriba similis & trace \\
& Lume & 12 & Tefepilachna & Chnootriba similis & $0-1$ \\
& Dugdabora & 3 & Tefepilachna & Chnootriba similis & $0-1.5$ \\
\multirow{3}{*}{ North Shewa } & Minjar-Shenkora & 10 & Tefepilachna & Chnootriba similis & $0-2.0$ \\
& & & Field mice & Arvicanthis niloticus & Localised damage \\
& & & & Desmarest & \\
\hline
\end{tabular}

concern in Ethiopian wheat unless the crop is sown late and exposed to terminal drought. Therefore, the absence of cereal aphids in the surveyed area of Ethiopia might be due to the appropriate planting time used by farmers to sow wheat.

In Mt. Kenya region most of the wheat was in the soft dough stage, and most aphids tend to disappear as crops tend to head (Macharia et al., 2004). However, symptoms of RWA infestation (leaf rolling and fishhook shaped ears) were evident. RWA was found in rolled leaves and trapped awns (Figs. 1 and 2). The rolled leaves protect RWA and other cereal aphid species from unfavourable weather and natural enemies (Valialus, 1986). The leaf rolling effect also allows other cereal aphids (M. dirhodum, R. maidis, and $R$. padi) to stay longer on the crop. In addition, leaf rolling of some wheat varieties, in response to drought conditions, provides shelter for some of the cereal aphids, thereby allowing them to stay longer on the crop (Macharia et al., 2002).
Farmers should scout their crops regularly for the presence of live aphids and symptoms of RWA damage. Scouting wheat fields for infested tillers is the most effective way to determine the need to control RWA on time and reduce crop damage.

Continuous cropping of wheat was practiced by wheat growers in Mt Kenya region and West Mau areas. This may have enabled the cereal aphids to migrate from one field to another and survive from one season to the next. Similar observations were reported by Mulatu and Gebremedhin (1994) in the highlands of Ethiopia, that where continuous cropping was practiced, cereal aphids tended to move from one field to another, depending on the growth stage of the crop. Wheat growers in such areas should use systemic insecticides applied as seed dressings or foliar systemic insecticides applied on scouting the early symptoms of cereal aphids' infestation. The seed dressing insecticides control the colonising migrant aphids, and prevents primary 


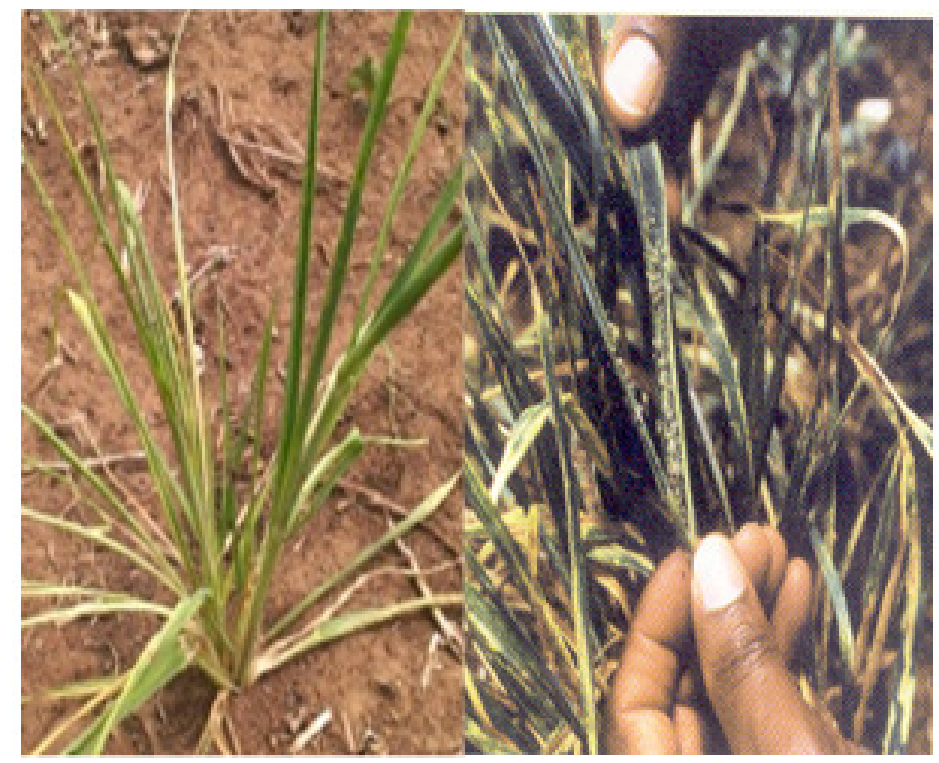

Figure 1. Russian wheat aphid feeding inside rolled leaves.

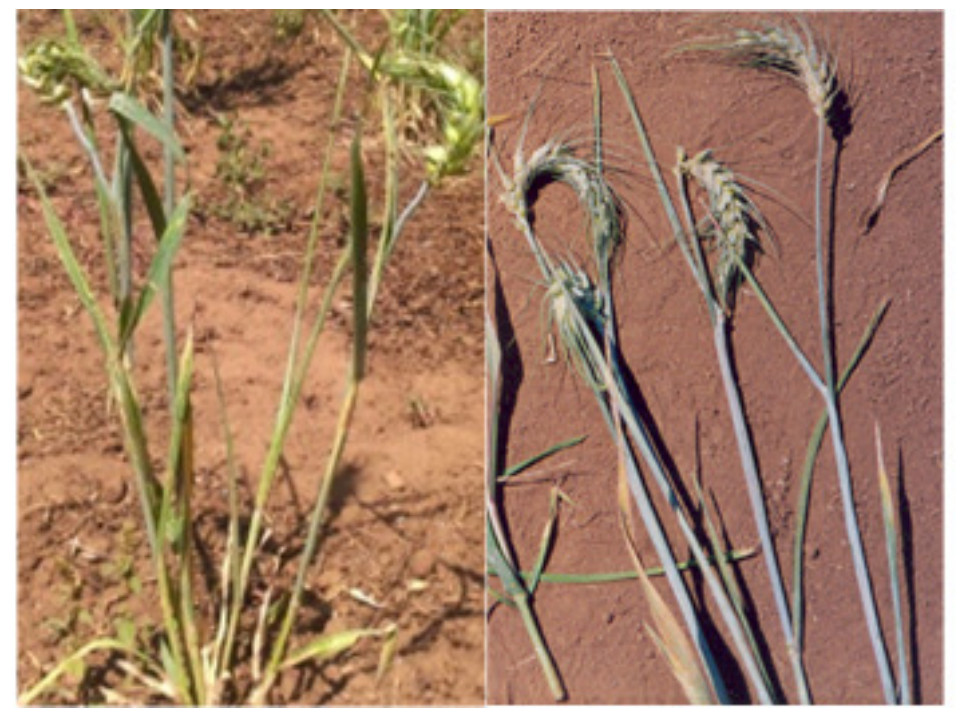

Figure 2. Fish hook shaped ears (trapped awns).

infestation. The foliar applied insecticides control the primary spread of cereal aphids ((Macharia $e t$ al., 2002).

Alternate hosts of RWA and other cereal aphids found during the survey in Kenya were wild oats Avena fatua L., brome grass, Bromus spp; wild rye grass Elymus spp and foxtail grass Setaria spp. These grass weeds are common in the high altitude wheat growing areas of Ethiopia
(Adugna and Tesema, 1987) and Mt. Kenya and West Mau regions of Kenya. They serve as reservoirs for cereal aphids during the dry weather. Neglected volunteer wheat, barley and oats plants were also important for the survival of RWA and other cereal aphids, as these served as reservoirs that could then infest a new crop when it emerged. Volunteer wheat, barley and wild grasses were reported by Armstrong et al. 
(1991) supporting RWA and thus provide a green bridge for infestation of the next season wheat crop. Wheat growers should monitor and control these alternate host plants that provide shelter during the off-season before seeding the wheat crop the following season.

The tef epilachna, Chnootriba similis (Coleoptera: Coccinellidae), infested only $39 \%$ of wheat fields in Ethiopia (Table 2). It was widely distributed both in the low- and high-land areas, although previously its distribution was believed to be limited to the mid-and low-land (an altitude of $<2000$ ma.s.1.) wheat growing areas of the country. Both the larvae and adults fed by scrapping the upper leaf surface (Bejlmakers, 1989); however, the overall infestation level was very low. Symptoms of shoot fly damages, i.e., dead heart, were encountered in one wheat field in each district (Lume and Minjar-Shenkora districts). Moreover, localised rodent damage (probably by Arvicanthis niloticus Desmarest) was recorded in the latter district. In these areas, crops were fenced with stone wall or live fences, which usually harbour rodents and other small vertebrate animals. During the survey period, no incidence of rodent damage on wheat crops was reported from both Kenya and Uganda.

The field survey in Uganda revealed that wheat was attacked by several pests. The pests collected during the survey; in decreasing order of importance, were cereal aphids, thrips, stemborers, pod borers, termites and slugs (Table 3 ). RWA was the most prevalent wheat pest in Uganda; followed by greenbug Schizaphis graminum (Table 3 ). The population density of
RWA was 38 and 14.7 aphids per tiller, in 2013 and 2014, cropping seasons, respectively. The number of green bug per plant was 28 aphids per tiller. The green stink bugs, Nezara viridula L., were the most prevalent in Budadiri district of Uganda and their population intensity was up to 4 bugs per tiller. The other insect pests were recorded at very low intensities.

Within the East Africa region, it is only in Uganda, where slugs and snails were observed as pests of wheat, unlike in Ethiopia and Kenya. Slugs and garden snails are pests of wheat found in northern Africa and are polyphagous, feeding on many other plant species. According to Douglas and Tooker (2012), slugs are serious pests of many crop species, including wheat, barley, oats, rye (Secale cereale L.); maize, and other crops in no- and reduced-tillage field crop production.

Natural enemies of cereal aphids. In Eastern Africa, it is only in Kenya, where predators and parasitoids of cereal aphids were reported during the survey period. Few types of predators and parasitoids attacked most of the cereal aphids in Kenya (Table 4). The predators were the Coccinellid beetle (Cheilomenes spp.), spiders (Arachnidea) and lacewings (Chrysopa spp), which are generalist predators occurring at very low density beginning from tillering and continues until the crop reached heading stage. These general predators are also known to prey on cereal aphid on wheat and barley in Ethiopia (Adugna and Tesema, 1987).

TABLE 3. Prevalence of insect pests and gastropods in wheat in Uganda

\begin{tabular}{llll}
\hline Class & Order & Common name & Scientific name \\
\hline Insecta & Hemiptera & Russian wheat aphid & Diuraphis noxia (Kurdijumov) \\
& Greenbug & Schizaphis graminum (Rondani) \\
& Thysanoptera & Thrips & Haplothrips tritici (Kurd.) \\
& Lepidoptera & Stem borers & Helicoverpa armigera (Hubner) \\
& Pod borer & Marcotermes spp \\
& Isoptera & Termites & \\
& & Slugs & Deroceras leave (Muller) \\
& Stylommatophora & Slugs & Helix aspersa (Muller) \\
& Stylommatophora & Garden snails & \\
& Pulmonata & &
\end{tabular}


TABLE 4. Predators and parasitoids attacking cereal aphids in wheat in Kenya

\begin{tabular}{lcccc}
\hline Predators and parasitoids & \multicolumn{4}{c}{ Cereal aphids species } \\
\cline { 2 - 5 } & $\begin{array}{c}\text { Diuraphis } \\
\text { noxia }\end{array}$ & $\begin{array}{c}\text { Metopolophium } \\
\text { dirhodum }\end{array}$ & $\begin{array}{c}\text { Rhopalosiphum } \\
\text { maidis }\end{array}$ & $\begin{array}{c}\text { Rhopalosiphum } \\
\text { padi }\end{array}$ \\
\hline Predators & & & & \\
Coleopteran beetles (Cheilomenes spp.) & $\mathrm{x}$ & $\mathrm{x}$ & $\mathrm{x}$ & - \\
Neuroptera (Lacewings) & $\mathrm{x}$ & $\mathrm{x}$ & $\mathrm{x}$ & $\mathrm{x}$ \\
Arachnoidea (Spiders) & $\mathrm{x}$ & $\mathrm{x}$ & & $\mathrm{x}$ \\
Parasitoids & $\mathrm{x}$ & $\mathrm{x}$ & - & $\mathrm{x}$ \\
Hymenoptera (Aphidius spp.) & $\mathrm{x}$ & & & \\
\hline
\end{tabular}

The only parasitoid that emerged from mummified RWA was Aphidius spp, although the rate of parasitism was very low and appeared late in the season. Generally, all these natural enemies occurred at different times during the cropping season, but often when the aphid population had passed the damaging level (Macharia et al., 2004). Therefore, they may be contributing to some control of RWA and other cereal aphids in the wheat crop. For instance, the study noted that natural enemies of RWA were only present late in the crop season, when damage to wheat crops had already taken place.

The rapid population increase of cereal aphids in wheat was attributed to the absence of successful aphid predators and parasitoids. There is need for understanding the population dynamics, including seasonal variation of these aphid species and their natural enemies, for development of an integrated pest management (IPM) package. Using insecticides indiscriminately can cause harm to these natural enemies (beneficial insects) too. Wheat growers should monitor and consider beneficial insects when making control decisions and after treatment application, continue monitoring to assess pest populations and their control.

\section{CONCLUSION}

The distribution of different insect pests across different wheat growing areas in Eastern Africa varies. The Russian Wheat Aphid is the most common pest of wheat in both Kenya and Uganda. The tef epilachna, $C$. similis, is the most common pest of wheat crops in East and North Shewa zones in Ethiopia; whereas damage by other pests such as the shoot-flies and rodents is localised. Volunteer wheat, barley and grasses support cereal aphids during the off-season in Kenya. All natural enemies occur at different times during the cropping season, and they may be contributing to season control of cereal aphids.

There is need for a further comprehensive study in all wheat growing areas in East Africa, in order to establish the pest status of insect pests associated with the wheat crop and their respective natural enemies. Sampling should occur throughout crop development, with the number of sites being apportioned on the basis of hectares under wheat production in each country.

\section{ACKNOWLEDGEMENT}

This study was financially supported by the Eastern Africa Agricultural Productivity Project (EAAPP) and the publication of this paper facilitated by the Association for Strengthening Agricultural Research in Eastern and Central Africa (ASARECA).

\section{REFERENCES}

Adugna Haile and Tesema Megenasa. 1987. Survey of aphids on barley in parts of Shewa, Welo and Tigrai, Ethiopia. Ethiopian Journal of Agricultural Sciences 9: 39-53.

Armstrong, J.S., Porter, M.R. and Peairs, F.B. 1991. Alternate hosts of the Russian wheat aphid 
(Homoptera: Aphididae) in north eastern Colorado. Journal of Economic Entomology 84: 1691-1694.

Bejlmakers, H. 1989. Insect pests of cereals in Ethiopia: Identification and Control measures. FAO/UNDP Project ETH/86/029 Crop Protection Phase II, Addis Ababa, Ethiopia, Oct 1989.

Douglas, M.R. and Tooker, J.F. 2012. Slug (Mollusca: Agriolimacidae, Arionidae) ecology and management in no-till field crops, with an emphasis on the mid- A t l a n t i c Region. Journal of Integrated Pest Management 3(1): DOI: http://dx.doi.org/ 10.1603/IPM11023

Gildow, F.E. 1990. Barley yellow dwarf virus transport through aphids. pp. 165-177. In: Peters, D.C., Webster, J.A. and Chlouber, C.S. (Eds.). Proceedings: Aphid-Plant interactions: Population to molecules. August 12-17, 1990, Stillwater, Oklahoma, USA.

Hailu Beyene, Franzel, S. and Mwangi, W. 1989. Constraints to increasing wheat production in Ethiopia's small-holder sector. pp. 284-293. In: Tanner, D.G. M. van Ginkel and Mwangi, W. (Eds.). 1990. Sixth Regional Wheat Workshop for Eastern, Central and Southern Africa. Mexico. D.F.: CIMMYT.

Irwin, M.E. and Thresh, J.M. 1988. Long-range aerial dispersal of cereal aphids as virus vectors in North America. Philosophical
Transactions of the Royal Society B: Biological Sciences 321: 421-446.

Macharia, M., Maling'a, and Kinyua M. G. 2002. Occurrence of Russian wheat aphid in Kenya: The problem and possible control strategies. Egerton University/KARI-NPBRC Symposium, 25- 26 November 2002, NPBRCNjoro, Kenya.

Macharia, M., Njuguna, M. and Koros, I. 2004. Survey of natural enemies of the Russian wheat aphid, Diuraphis noxia (Kurdijumov) in Kenya. pp.161-165. In: Kinyua, M.G, Kamwaga, J., Owuoche, J.O., Ndiema, A.C., Njau, P.N., Friesen, D.K. and Ouya, D. (Eds). 2006. Proceedings of the $12^{\text {th }}$ Regional Wheat Workshop for Eastern, Central and Southern Africa, Nakuru, Kenya, 22-26 November 2004.

Mulatu, B.M. and Gebremedhin, T. 1994. Russian wheat aphid, a major pest of barley in Ethiopia. pp. 169-174. In: Peairs, F.B., Kroening, M.K. and Simmons, C.L. (Eds.). Proceedings of the Sixth Russian Wheat Aphid Workshop, January 23- 25, 1994, Colorado State University, Ft. Collins, Colorado, USA.

Oerke, E.C. 2005. Crop losses to pests. Journal of Agricultural Science 144: 31-43.

Valiulus, D. 1986. Russian Wheat Aphid: A new pest that may be here to stay. Agrochemical Age 30: 10-11.

Zadoks, J.C., Chang, T.T. and Konzak, C.F. 1974. A decimal code for the growth stages of cereals. Weed Science 14: 415-421. 